\title{
Transformasi Pengembangan Materi Pendidikan Agama Islam dengan Nilai Islam Indonesia (dari Pendekatan Monodisipliner menuju Pendekatan Interdisipliner)
}

\author{
Hawwin Muzakki', Ahmad Natsir ${ }^{2}$, Ahmad Fahrudin ${ }^{3}$ \\ ${ }^{1}$ UIN Sayyid Ali Rahmatullah Tulungagung \\ 2UIN Sayyid Ali Rahmatullah Tulungagung \\ ${ }^{3}$ UIN Sayyid Ali Rahmatullah Tulungagung
}

\author{
Keywords: \\ Learning Transformation, \\ Islamic Religious Education, \\ Monodisciplinary, \\ Interdisciplinary.
}

Kata Kunci :

Transformasi, Pengembangan Materi, Pendidikan Agama Islam, Monodisipliner, Interdisipliner.

\footnotetext{
*Correspondence Address: hawwin100@gmail.com
}

\begin{abstract}
Islamic education is open to any ideas that come from other knowledge groups. This open-access should make religious teachers start thinking about conveying the perspective of Islam using an interdisciplinary approach, rather than a monodisciplinary approach. This study initiated the development of Islamic education material using an interdisciplinary approach, with the formulation of the problem: first, what are the concepts and weaknesses of Islamic education material development using a monodisciplinary approach? second, how are the concepts, procedures, and stages of transformation in the development of Islamic education materials with Indonesian Islamic values using an interdisciplinary approach? The purpose of this study is to read the transformation process of the development of Islamic Education materials with Indonesian Islamic values. Through a qualitative approach, content analysis, and qualitative descriptive methods. This study concludes: first, the concept of developing Islamic education material using a monodisciplinary approach still uses only one family of religious knowledge in its delivery, which results in an exclusive understanding of religion. Second, the concept of Islamic education learning material that uses an interdisciplinary approach can present religious studies by involving social studies, humanism, environmental issues, gender, Indonesianness, and politics. The procedures and stages using the 4-D Model.
\end{abstract}

Abstrak: Pendidikan Agama Islam sejatinya terbuka terhadap setiap gagasan yang masuk dari rumpun ilmu yang lain. Akses terbuka tersebut, seharusnya membuat para pengajar Agama mulai berfikir untuk menyampaikan perspektif Agama Islam menggunakan kajian pendekatan interdisipliner, daripada monodisipliner. Penelitian ini menggagas pengembangan materi PAI menggunakan pendekatan Interdisipliner, dengan rumusan masalah : pertama, Bagaimana konsep dan kelemahan pengembangan materi PAI menggunakan pendekatan monodisipliner? kedua, bagaimana konsep, prosedur dan tahapan transformasi pengembangan materi PAI dengan nilai Islam Indonesia menggunakan pendekatan Interdisipliner? Adapun tujuan penelitian ini untuk membaca proses transformasi pengembangan materi Pendidikan Agama Islam dengan nilai Islam Indonesia. Melalui pendekatan kualitatif, metode content analysis dan deskriptif kualitatif. Penelitian ini menyimpulkan: pertama, konsep pengembangan materi PAI yang menggunakan pendekatan monodisipliner masih menggunakan satu rumpun ilmu agama saja dalam penyampaiannya, yang mengakibatkan pemahaman ekslusif dalam beragama. Kedua, konsep materi pembelajaran PAI yang menggunakan pendekatan Interdisipliner 
mampu menampilkan kajian beragama dengan melibatkan kajian sosial masyarakat, humanisme, persoalan lingkungan, gender, keIndonesiaan, dan politik. Prosedur dan tahapannya menggunakan model 4-D.

\section{INTRODUCTION}

Indonesia dihadapkan dengan kondisi keanekaragaman suku, agama, budaya, bangsa sejak awal mula berdirinya pada tahun 1945. Sehingga konflik keagamaan, perbedaan suku, ras dan golongan di Indonesia tidak bisa dihindarkan. Isu-isu tentang mayoritas dan minoritas dalam beragama, kekerasan suku yang berimbas pada isu disintegrasi dan menyuaraknya kepentingan golongan tertentu pada isu-isu kepemimpinan nasional serta munculnya berbagai konflik-konflik horizontal yang lain.

Di satu sisi, keberagaman ini merupakan kekuatan sosial yang indah dan bagus dalam konsep kenegaraan, ketika bisa saling berkolaborasi dan membangun sebuah negara secara bersama. Namun di sisi lain, jika berbagai keberagaman ini tidak dikelola dan ditata dengan baik, akan menjadi penyebab konflik dan kekerasan, serta mengguncang negara serta kehidupannya. ${ }^{1}$

Perpecahan bangsa Indonesia sebagian besar bermula dari paham liberal dan ekstrimis yang masuk dalam ajaran Islam yang bergerak dengan sembunyi-sumbunyi. Paham liberal yang mengajarkan kebebasan mengancam moral ke-Timuran, dan akhirnya membentuk pemahaman

\footnotetext{
1 Hawwin Muzakki, 'Integrasi Nilai-Nilai Religius dan Nasionalisme pada Pendidikan Anak Usia Dini', in Prosiding ISLAGE-2 Kemenag RI (ISLAGE-2, sentul, Bogor, n.d.), 32, accessed 21 April 2021.

2 Khoirul Mudawinun, 'Integrasi Nilai-Nilai Moderasi Pada Pendidikan Anak Usia Dini Berbasis Living Values Education (LVE)', in Proceedings of Annual Conference for Muslim Scholars, 2018, 271.
}

Islam yang radiks, bebas dan tak terkendali. Satu sisi, mengakibatkan munculnya ajaran Islam transnasional, dengan menghilangkan batas-batas negara, lahirlah ekstremisme yang menyebar luas di masyarakat Indonesia. Beberapa aliran ekstrim ingin memberontak atau membangkang dari sistem negara dengan melakukan teror. ${ }^{2}$

Akhir-akhir ini, perdamaian di Indonesia kembali terusik, tepatnya tanggal 28 Maret 2021 terjadi serangan bom di halaman depan gereja Katedral Makassar dan serangan teror yang menggunakan senjata pistol di Mabes Polri tanggal 31 Maret 2021. ${ }^{3}$ Tahun sebelumnya ada beberapa aksi bom bunuh diri, misalnya di 3 gereja Surabaya (13 Mei 2018), Mapolrestabes Surabaya (14 Mei 2018), ledakan bom di Rusunawa wonocolo Sidoarjo (13 Mei 2018) dan serangan teroris di Mapolda Riau (16 Mei 2018). ${ }^{4}$

Di masyarakat sempat terjadi perdebatan panjang, apakah teroris mempunyai agama? Viralnya pertanyaan tersebut terkait dengan pernyataan dari wakil ketua MUI yang mengatakan bahwa "bom di Makassar jangan dikaitkan dengan agama". Namun, fakta di lapangan tidak bisa di hindari, khususnya di Indonesia, para pelaku bom bunuh diri saat ini

\footnotetext{
3 Jawahir Gustav Rizal, 'Terjadi Ledakan Bom Bunuh Diri, Gereja Katedral Makassar Trending di Twitter Halaman all', KOMPAS.com, 30 March 2021.

${ }^{4}$ Palupi Annisa Auliani, 'Lokasi Ledakan Bom Surabaya dalam Peta', KOMPAS.com, 13 May 2018, https://regional.kompas.com/read/2018/05/13/ 17512651/lokasi-ledakan-bom-surabaya-dalampeta.
} 
dikaitkan dengan pemahaman atas agama tertentu, terutama agama Islam, karena atribut-atribut yang digunakannya.

Sebenarnya, persoalan terorisme sudah mendapat perhatian khusus dari pemerintah Indonesia. Salah satunya dengan meningkatkan sistem keamanan dan pengesahan RUU terorisme sebagai upaya kuratif. Namun, untuk pencegahannya pemerintah belum melakukannya secara maksimal, karena secara khusus pemerintah belum membuat kebijakan untuk mentransformasikan nilai Islam Indonesia ke dalam Materi Pendidikan Agama Islam (PAI) dengan menggunakan kajian Interdisipliner.

Saat ini, pembelajaran PAI dalam praktiknya masih menggunakan pendekatan monodisipliner 5 Pembelajaran yang menggunakan pendekatan monodisipliner, disinyalir membuat pemahaman peserta didik menjadi lebih terbatas dan eksklusif. Mengapa demikian? karena dalam kajian monodisipliner cenderung membatasi diri dari pandangan satu perspektif, dan juga menutup pintupintu kajian yang lain. Sehingga informasi yang didapatkan menjadi sedikit.

Kondisi pendidikan saat ini, merupakan gambaran bagaimana kondisi Indonesia pada masa generasi emas tahun 2045 mendatang. Untuk mewujudkan cita-cita pendidikan Indonesia yaitu menciptakan siswa yang bijaksana, beriman dan bertakwa, terampil, bermoral dan cerdas. Pendidikan agama Islam di sekolah menempati andil yang besar dalam

5 Nimawati Nimawati, Uus Ruswandi, and Mohamad Erihadiana, 'Kajian Riset Monodisipliner dan Interdisipliner dalam pendidikan islam Menghadapi Isu Nasional dan Global: Studi Kasus Terhadap Isu Covid-19', MISYKAT: Jurnal Ilmu-ilmu Al-Quran, Hadist, Syari'ah dan Tarbiyah 5, no. 1 (30 merealisasikan cita-cita pendidikan yang luhur tersebut.

Selain itu, materi PAI sejatinya terbuka terhadap setiap gagasan yang masuk dari rumpun-rumpun ilmu yang lain. Akses terbuka tersebut, seharusnya membuat para pengajar Agama mulai berfikir untuk menyampaikan perspektif Agama Islam menggunakan ilmu-ilmu di luar rumpunnya (interdisipliner). Di tengah modernitas, kajian keagamaan juga seharusnya mengalami pembaharuan untuk merespon kekinian, namun tetap tidak meninggalkan ajaran pokok yang terdapat di Al-Qur'an dan Hadis.

Berdasarkan penelusuran peneliti, belum ada penelitian sejenis, yang mengkaji persoalan dengan fokus kajian transformasi materi PAI dengan Nilai Islam Indonesia menggunakan pendekatan Interdisipliner. Penelitian dari Durhan dengan judul "Integrasi Nilai-Nilai Nasionalisme dalam Pendidikan Agama Islam dengan Pendekatan Interdisipliner", menggunakan metode content analysis dan diskriptif analisis, menyimpulkan 2 hal yaitu (1) Peserta didik mampu mengetahui nilai-nilai nasionalisme dan PAI. (2) Peserta didik mampu mengetahui pendekatan Interdisipliner dalam mata pelajaran PAI. ${ }^{6}$

Penelitian oleh Nino Indrianto dengan judul "Rancangan Bahan Ajar Pendidikan Agama Islam dengan Pendekatan Interdisipliner di Perguruan Tinggi", menggunakan metode RnD, menyimpulkan bahwa bahan ajar PAI dengan pendekatan interdisipliner menarik, valid dan

June 2020): 1, https://doi.org/10.33511/misykat.v5n1.101-122. 6 Durhan Durhan, 'Integrasi Nilai-Nilai Nasionalisme Dalam Pendidikan Agama Islam Dengan Pendekatan Interdisipliner', AHSANA MEDIA 6, no. 1 (2020): 51. 
efektif untuk meningkatkan hasil belajar mahasiswa di Universitas. Kedua penelitian tersebut masih terbatas dan belum menyentuh aspek substansi dari pengembangan PAI menggunakan pendekatan Interdisipliner dengan nilai Islam Indonesia di jenjang Sekolah Menengah Atas. ${ }^{7}$

Penelitian ini menggagas pembelajaran Pendidikan Agama Islam di era digital ini menggunakan pendekatan Interdisipliner, dengan rumusan masalah: pertama, bagaimana konsep dan kelemahan pengembangan materi PAI menggunakan pendekatan monodisipliner? kedua, bagaimana konsep, prosedur dan tahapan transformasi pengembangan materi PAI dengan nilai Islam Indonesia menggunakan pendekatan Interdisipliner? Adapun tujuan penelitian ini untuk membaca proses transformasi pengembangan materi Pendidikan Agama Islam dengan nilai Islam Indonesia.

\section{METODE}

Dalam penelitian ini, peneliti menggunakan 2 metode penggalian data. Untuk menganalisis buku PAI yang diterbitkan oleh pemerintah menggunakan content analysis dan melibatkan hasil penelitian yang sejenis untuk mendukung data dari peneliti. Sedangkan untuk menggali konsep, prosedur dan tahapan pengembangan materi PAI Model Kajian Interdisipliner dengan Nilai Islam Indonesia, menggunakan metode deskriptif kualitatif.

\section{HASIL DAN PEMBAHASAN Nilai-nilai Islam Indonesia}

7 Nino Indrianto, 'Rancangan Bahan Ajar Pendidikan Agama Islam Dengan Pendekatan Interdisipliner Di Perguruan Tinggi: Studi Pengembangan Di Fakultas Keguruan Dan Ilmu Pendidikan Universitas Jember Dan Fakultas Ilmu
Ajaran agama beserta doktrin serta dogma di dalamnya tidak seluruhnya merupakan aturan yang kolot, stagnan dan tidak berubah. Oleh karena itu, seiring dengan perubahan budaya, ajaran agama juga melalui proses perubahan. Fakta ini membuka pemahaman masyarakat bahwa tidak cukup hanya mempelajari agama dari satu sisi ilmiah saja, karena pada realitasnya agama juga muncul sebagai entitas yang tidak terpisahkan dari posisi manusia sebagai makhluk yang beriman. Artinya di satu sisi ajaran agama juga bisa dipelajari dari perspektif sosiologis, sehingga ilmuilmu lain bisa ikut serta dalam kajian ajaran agama. Sehingga memungkinkan terjadinya sebuah transformasi dari masa ke masa. ${ }^{8}$

Sejalan dengan pandangan Berger, hal ini menegaskan keberadaan adanya kontruksi pada ajaran agama, yang ke depannya akan mampu mengubah wajah baru ajaran agama, termasuk Islam. Saat Islam lahir di negara Arab, bahkan banyak tradisi Arab yang dipertahankan dalam ajaran Islam. Artinya Nabi Muhammad tidak sepenuhnya membawa doktrin baru untuk menghilangkan tradisi lokal Arab yang ada. Tradisi yang baik diterima dan dibangun kembali, sedangkan tradisi yang buruk digantikan oleh ajaran yang lebih baik. Demikian juga yang terjadi di Indonesia, Islam yang berinteraksi dengan budaya masyarakat Indonesia sehingga terjadi proses rekonstruksi, dekonstruksi dan akulturasi budaya, sehingga mendorong lahirnya konsep Islam Indonesia atau Islam Nusantara.

\footnotetext{
Pendidikan Universitas Negeri Surabaya' (PhD Thesis, UIN Sunan Ampel Surabaya, 2019), 5.

8 Rudy Harold, 'Agama Dan Pembentukan Realitas Dalam Pandangan Peter Ludwig Berger', Cakrawala 5, no. 1 (2016): 143.
} 
Nilai Islam Indonesia adalah nilai religius yang digali dari kebudayaan masyarakat Indonesia, yang sesuai dengan kondisi masyarakat, misalkan aspek etika yang dianut, kondisi sosial, budaya, geografis, ekonomi, dan halhal lain yang mengitarinya. Melalui pembacaan dari berbagai referensi, ditemukan beberapa indikator nilainilai Islam Indonesia, yaitu: Tawassuth, I'tidal, Tawazun, Musawah, Tasamuh, Ishlah, Syura, Aulawiyah, Tathawwurwa Ibtikar dan Tahadhdhur. Dengan penjelasannya berikut ini:

a. Tawassuth yaitu mengambil jalan tengah dengan mempraktekkan ajaran agama dengan tidak berlebihan, dan tidak menguranginya.

b. Tawazun memahami ajaran agama secara seimbang baik dunia maupun akhirat.

c. I'tidal yaitu lurus, tetap di tempat dengan menjalankan hak dan memenuhi kewajiban secara proporsional

d. Tasamuh yang berarti pengakuan dan penghormatan terhadap perbedaan agama dan segala aspek kehidupan

e. Musawah (egaliter), yaitu tidak membeda-bedakan orang lain karena perbedaan keyakinan, tradisi dan asal-usul

f. Syura (musyawarah), yaitu prinsip supremasi kepentingan kemaslahatan bersama, melalui musyawarah untuk menyelesaikan setiap masalah dan mencapai mufakat.

g. Ishlah (reformasi), yaitu prioritas diberikan pada prinsip-prinsip reformasi

${ }^{9}$ Afrizal Nur, 'Konsep Wasathiyah dalam Al-Quran; (Studi Komparatif antara Tafsir Al-Tahrîr Wa AtTanwîr dan Aisar At-Tafâsîr)', Jurnal An-Nur 4, no. 2 (27 September 2016): 5. Lihat juga Hawwin untuk mencapai kondisi yang lebih baik untuk beradaptasi dengan perubahan zaman agar menjadi semakin lebih baik.

h. Aulawiyah adalah kemampuan untuk menyadari bahwa hal-hal yang lebih penting harus didahulukan daripada hal-hal yang kurang penting; memprioritaskan kepentingan umum daripada kepentingan individu.

i. Tathawwurwa Ibtikar yaitu terbuka pada zaman yang selalu berubah untuk kemaslahatan dan kemajuan umat manusia

j. Tahadhdhur yaitu memiliki keagungan akhlak, berkarakter, memiliki jatidiri sebagai sebaik-baiknya umat dalam kehidupan kemanusiaan dan peradaban. $^{9}$

Sepuluh nilai-nilai Islam Indonesia tersebut yang akan penulis terapkan untuk mentransformasi materi PAI, menggunakan pendekatan Interdisipliner.

\section{Konsep dan Kelemahan Pengembangan Materi PAI Menggunakan Pendekatan Monodisipliner}

Materi yang dikembangkan menggunakan kajian monodisipliner adalah materi yang hanya menggunakan satu perspektif ilmu dalam kajiannya. Misalkan kajian Agama, hanya melibatkan ilmu-ilmu agama dalam pembahasannya, belum masuk kajian dari perspektif ilmu yang berlainan. Berikutnya, penulis akan memfokuskan materi PAI di SMA mulai kelas X, XI dan XII. Kondisi saat ini,

Muzakki, 'Mengukuhkan Islam Nusantara: Kajian Sosiologis-Historis', An-Nuha: Jurnal Kajian Islam, Pendidikan, Budaya Dan Sosial 6, no. 2 (10 December 2019): 215. 
pembelajaran agama masih menggunakan kajian monodisipliner, dengan melibatkan satu disiplin ilmu agama yang berdasar pada Al-Qurán, Sunnah, Ijtihad, Qiyas dan pelibatan Sejarah Kebudayaan Islam.

Setiap materi ajar yang disusun pasti ada segi kelemahan dan kelebihan. Penulis ingin menunjukkan beberapa kelemahan materi PAI yang disusun menggunakan kajian monodisipliner yang diterbitkan oleh Kemendikbud. Objek penelitian pada rumusan masalah yang pertama ini adalah buku-buku PAI yang diterbitkan oleh Kemendikbud pada jenjang SMA. Beberapa kelemahan yang ditinjau oleh penulis, akan diuraikan berikut ini:

a. Kajian tentang Sejarah Kebudayaan Islam dengan tema khalifah. Informasi yang diberikan kepada siswa tidak berimbang atau berat sebelah. Perlu adanya kajian yang komprehensif untuk mengungkap sejarah secara kritis. Agar para siswa-siswi mengetahui kelemahan dan kelebihan khalifah masing-masing dinasti Islam.

\section{Banyak khalifah pencinta ilmu, misalnya Khalifah al-Makmum yang mengembangkan Baitul Hikmah menjadi lembaga pendidikan tinggi terkemuka yang mengajarkan berbagai bahasa, metode penerjemahan, dan penelitian ilmiah. Khalifah juga memiliki semangat mengumpulkan manuskrip-manuskrip berharga dari negeri-negeri sekitarnya, seperti Byzantium, Iran, India, Mesir, dan Yunani.}

Gambar 1. Buku PAI Kelas XI

Kecenderungan di Buku SMA mengungkapkan hanya kelebihankelebihan dari khalifah. Contohnya pernyataan "banyak khalifah pencinta ilmu misalnya al-Makmun", ${ }^{10}$ padahal al-Makmun juga mempunyai kelemahan, ia melakukan proses mihnah yaitu

10 Kementerian Agama Republik Indonesia, Pendidikan Agama Islam Dan pemaksaan terhadap ulama' pada waktu itu agar berpaham Mu'tazilah dan mengakui bahwa Al-Qur'an adalah makhluk, bukan qadim. Sehingga kebijakan mihnah ini juga banyak menyiksa ulama'ulama' yang berbeda paham dengan mu'tazilah. Dan informasi ini jarang ditemukan di buku-buku pelajaran PAI. Mengapa informasi ini penting untuk ditunjukkan kepada siswa SMA? Hal ini dengan tujuan untuk memberikan informasi khalifah/ pemimpin Islam secara berimbang dan seimbang, tidak hanya menonjolkan aspek-aspek yang baik saja. Bahwa khalifah juga manusia biasa, yang juga punya cerita soal kekejaman, intrik politik, model kekuasaan dan sebagainya.

Di temuan penelitian lain atas pembacaan buku PAI buatan Kemendikbud, mengenai tema khalifah ini menyimpulkan adanya dugaan radikalisme dan intoleransi atas teks yang menyatakan bahwa khalifah adalah penguasa di seluruh dunia Islam yang mengurusi bidang politik dan agama. Lalu ada syarat khusus bahwa khalifah wajib mujtahid besar dan menerapkan syariat Islam. Sehingga kontra produktif atas teks yang berkembang di negara demokrasi seperti Indonesia yang menyatakan bahwa kepala negara boleh dijabat dari orang muslim maupun non muslim.

Teks-teks seperti itu dalam buku mata pelajaran PAI di jenjang SMA hendaknya ditampilkan dari berbagai sudut pandang yang berbeda. Sehingga bisa menghormati 
antar pemeluk ajaran lain dalam konteks menjaga kedaulatan dan Negara Kesatuan Republik Indonesia. ${ }^{11}$

b. Masih sedikit untuk menerapkan akhlak al-karimah melalui model Living Value Education agar pembelajaran akhlak menjadi sebuah karakter dalam diri siswa. Di buku PAI yang diterbitkan oleh kemendikbud, penerapan akhlak ini hanya diuji menggunakan angket dan tabel anjuran untuk menerapkan karakter. Sebenarnya, perlu sebuah metode khusus dan praktek nyata yang bisa benar-benar diterapkan, untuk membentuk akhlak siswa, kemudian menjadi karakternya. Apalagi ini sebuah program Uuggulan pendidikan Indonesia, mengenai pendidikan karakter. Namun pesan ini belum tersampaikan pada buku PAI buatan kemendikbud. ${ }^{12}$

\section{Penerapan Karakter}

Setelah mengkaji materi tentang "Meraih Kedamaian dengan Mujahadah an-Nafs, Husnuzhan, dan Ukhuwwah", diharapkan kalian dapat dapat menerapkan karakter dalam kehidupan sehari-hari sebagai berikut:

\begin{tabular}{|c|l|l|}
\hline No & \multicolumn{1}{|c|}{ Butir Sikap } & \multicolumn{1}{|c|}{ Nilai Karakter } \\
\hline 1 & $\begin{array}{l}\text { selalu berzikir kepada Allah Swt. agar } \\
\text { terhindar dari perbuatan dosa }\end{array}$ & $\begin{array}{l}\text { religius, jujur, tanggung- } \\
\text { jawab }\end{array}$ \\
\hline 2 & $\begin{array}{l}\text { tidak mengumpat, ketika teman } \\
\text { melakukan kesalahan }\end{array}$ & cinta damai \\
\hline 3 & $\begin{array}{l}\text { meminta maaf kepada teman jika } \\
\text { bersalah }\end{array}$ & bersahabat \\
\hline
\end{tabular}

Gambar 2. Buku PAI Kelas X
1. Penilaian Sikap

A. Lakukan tugas rutin kalian, baik yang terkait dengan ibadah mahdah (ritual), seperti salat, puasa sunah, membaca al-Qur'an maupun ibadah sosial seperti membantu teman, kerja bakti dan lain-lain dengan dengan ikhlas dan senang hati, begitu juga perilaku yang terkait dengan materi seperti kontrol diri, prasangka baik, dan menjaga persaudaraan, kemudian catat semua yang kalian lakukan di buku catatan!

B. Berilah tanda centang $(\sqrt{ })$ pada kolom berikut dan berikan alasannya!

Gambar 3. Buku PAI Kelas X

c. Masih terdapat adanya jarak antara kajian agama dan kajian non agama. Kedua kajian tersebut nampak terpisah, sehingga terindikasi adanya sekularisme. Misalnya persoalan alam/lingkungan, orang muslim sudah diingatkan akan pentingnya hablun minannas, hablun minal 'alam dan hablun minallah. Sudah menjadi tugas umat muslim untuk menjaga alam dan lingkungan. Ulama' (orang yang berilmu) hendaknya tidak hanya di generalisir soal keahlian dalam ilmu agama, tapi label itu hendaknya juga berlaku untuk orang yang menguasahi ilmu umum dan kepeduliannya terhadap lingkungan. Sangat sedikit sekali mengenai informasi dan anjuran ihsan kepada alam semesta, hanya 1 paragraf. Sehingga ada anggapan, menjaga alam bukan tugasnya kita sebagai umat muslim di Indonesia di tengah ramainya pembalakan liar dan ekslpoitasi alam. ${ }^{13}$
11 Didin Syafruddin, 'Analisis Muatan Radikalisme Dalam Buku Teks Pendidikan Agama Islam (PAI) SMA' (Master's Thesis, Jakarta: FITK UIN Syarif Hidayatullah Jakarta, n.d.), 65.

12 Kementerian Agama Republik Indonesia, Pendidikan Agama Islam Dan Budi Pekerti Kelas X
Revisi 2019 (Jakarta: Kementerian Agama, 2019), 21.

13 Kementerian Agama Republik Indonesia, Pendidikan Agama Islam Dan Budi Pekerti Kelas XII Revisi 2019 (Jakarta: Kementerian Agama, 2019), 124. 
j. Ihsān kepada Alam Sekitar

Alam raya beserta isinya diciptakan untuk kepentingan manusia. Un kepentingan kelestarian hidup alam dan manusia sendiri, alam ha dimanfaatkan dengan penuh rasa tanggungjawab. Allah Swt. berfirm "...dan berbuat baiklah (kepada orang lain) sebagaimana Allah Swt. $t$ berbuat baik, kepadamu, dan janganlah kamu berbuat kerusakar (muka) bumi. Sesungguhnya Allah Swt. tidak menyukai orang-orang y berbuat kerusakan." (Q.S. al-Qáśáś/28:77).

Gambar 4. Buku PAI Kelas XII

d. Perlu pelibatan kajian gender untuk menggali relasi yang seimbang antara laki-laki dan wanita. Kajian ini penting untuk menghalau maraknya isu-isu salafi yang bersifat puritan ${ }^{14}$, misalnya melarang perempuan untuk bekerja di luar rumah, harus memakai cadar, niqab, selain itu untuk membentengi remaja akan gencarnya promosi poligami. Di buku PAI keluaran kemendikbud belum ada sama sekali pelibatan gender atau kajian Tafsir Mubadalah misalnya, terkait relasi antara laki-laki dan wanita. Di era modern ini, persoalan persamaan derajat, memulyakan wanita, relasi yang berimbang antara suami dan istri juga perlu untuk di angkat dalam buku-buku ajar PAI.

e. Adanya materi kajian tentang tokoh pembaharu Islam, misalnya: Muhammad Abduh, Rasyid Ridho, Jamaluddin al-Afghani, dan sebagainya. Pertama, konsep utamanya yaitu memunculkan ide purifikasi (memurnikan ajaran Islam). Di sisi lain menimbulkan penolakan terhadap tradisi dengan term-term lainnya semisal isu-isu tahayul, bid'ah, dan khurofat. Padahal kita punya tradisi yang bisa dijadikan untuk

14 Arrazy Hasyim, 'TEOLOGI MUSLIM PURITAN: Genealogi dan Ajaran Salafi', 2017, https://repository.uinjkt.ac.id/dspace/handle/12 $3456789 / 44986$. pengembangan jati diri bangsa dan dikembangkan secara luas untuk kemajuan Islam Indonesia. ${ }^{15}$

Banyak negara muslim mengikuti gerakan pembaruan tersebut, sehingga lahirlah suatu tatanan baru dalam dunia Islam, yaitu kebangkitan dunia Islam, baik bidang ilmu pengetahuan, politik, pendidikan, maupun kebangkitan melawan penjajah. Usaha untuk memulihkan kembali kekuatan Islam dikenal dengan gerakan modernisasi atau pembaruan yang didorong oleh tiga faktor.

a. Pemurnian ajaran Islam dan unsur-unsur asing yang dipandang sebagai penyebab kemunduran Islam.

Gambar 5. Buku PAI Kelas XI

Kedua, siswa perlu diberikan pemahaman tentang maqashid syar'i untuk membaca modernitas. Misalnya untuk membaca kebijakan bunga bank, asuransi, uang kertas, obligasi, saham dan sebagainya. Seperti yang diungkapkan M. Syafii Antonio, bahwa Islam mengatur seluruh aspek kehidupan, termasuk politik dan ekonomi. Sehingga mengindikasikan agar siswa mendukung adanya penerapan syariah Islam dan ekonomi Islam di Indonesia, yang disinyalir bisa merusak seluruh tatanan politik dan ekonomi yang sudah berjalan selama ini. ${ }^{16}$

Ekonomi Islam dalam Bahasa Arab disebut dengan istilah al-mu'amalah al-madiyah, yaitu aturan-aturan tentang pergaulan dan perhubungan manusia mengenai hidupnya. Ekonomi Islam bukan lahir sebagai suatu disiplin ilmu tersendiri, melainkan bagian integral dari agama Islam. Sebagai ajaran yang lengkap, Islam memberikan petunjuk terhadap semua aktivitas manusia, termasuk ekonomi. Karena sudah menjadi bagian dari agama Islam, maka ekonomi Islam memiliki sifat dasar sebagai ekonomi Rabban dan Insani. Rabbani karena sarat dengan arahan dari nilai-nilai Ilahiah. Sedangkan ekonomi Islam dikatakan sebagai ekonomi insani, karena sistem ekonominya dilaksanakan dan ditujukan untuk kemakmuran manusia.

Gambar 6. Buku PAI Kelas XI

Ketiga, guru saat menjelaskan tema ini harus secara hati-hati atau setidaknya melakukan interpretasi ulang terhadap seluruh ide dan gagasan para pembaharu Islam. Misalkan Jamaluddin al-Afghani menghendaki adanya pan-

15 Kementerian Agama Republik Indonesia, Pendidikan Agama Islam Dan Budi Pekerti Kelas XI Revisi 2019, 229.

${ }^{16}$ Kementerian Agama Republik Indonesia, 270. 
Islamisme yang artinya berbeda dengan konsep nation state/ nasionalisme yang dianut umat muslim di Indonesia. Hal ini tentunya kalau tidak disampaikan dengan hati-hati, akan bertumbuh subur ide-ide disintegrasi di kalangan remaja muslim Indonesia. $^{-17}$

2) menggulirkan pan-Islamisme, yaitu paham yang ber mempersatukan seluruh umat Islam di dunia. Hal melatarbelakangi pemikiran tersebut adalah dominasi kı Barat di dunia Islam pada masa itu;

Gambar 7. Buku PAI Kelas XI

Di temuan penelitian lain atas pembacaan buku PAI buatan Kemendikbud mengenai tema ini dijelaskan tentang ide-ide pemikiran hukum Rasyid Ridho yang teridentifikasi perlunya menghidupkan kembali sistem khalifah. Teks di atas mengindikasi masuknya muatan radikalisme secara terselubung pada materi dengan tema pembaruan Islam dan menyatukannya dalam konteks transnasional, Islam sebagai basis persatuan umat dengan menghilangkan batas-batas wilayah negara. Inilah yang nantinya ditakutkan mengancam konsep negara milik pemerintah Indonesia. $^{18}$

Hasil telaah awal di atas, menyimpulkan bahwa konsep pengembangan materi PAI yang menggunakan pendekatan monodisipliner masih menggunakan satu rumpun ilmu agama saja dalam penyampaiannya, yang mengakibatkan pemahaman ekslusif dalam beragama. Misalnya persoalan khilafah, penerapan Akhlak yang masih 304. sedikit, pengharaman tradisi, tidak peka pada persoalan lingkungan, bias gender dan pemikiran beberapa tokoh pembaharu yang mengakibatkan berfikir ekstrim.

\section{Konsep Pengembangan Materi PAI Menggunakan Pendekatan Interdisipliner}

Dalam pembahasan ini penulis akan menguraikan pengembangan materi PAI berwawasan Islam Indonesia melalui pendekatan Interdisipliner dengan melibatkan ilmu di luar non agama. Seperti berikut ini:

a. Pengembangan materi PAI berwawasan Islam Indonesia melalui pendekatan interdisipliner dengan melibatkan ilmu sejarah. Namun pelibatan ilmu sejarah dalam hal ini disajikan melalui fakta-fakta yang ada dalam kitab klasik misalnya siroh Ibn Hisyam, Siroh Ibn Katsir, kajian sejarah milik Abid al Jabiri, Izzat Darwazah dan tokoh-tokoh lainnya. Penyajian sejarah secara komprehensif dan seimbang, berguna untuk instropeksi diri dan jujur melihat fakta sejarah.

Bercermin dari pembelajaran SKI, jika sejarah terlalu banyak mengungkap sisi negatif, maka kita akan masuk ke dalam alam bawah sadar kita, yaitu sejarah kelam dan buram yang berakibat fatalisme, sikap pasrah gampang menyerah dan tidak bersenmangat dalam menghadapi hidup. Namun, jika terlalu bannyak mengungkap sisi positif kehidupan masa lampau, persoalan keunggulan khilafah

18 Syafruddin, 'Analisis Muatan Radikalisme Dalam Buku Teks Pendidikan Agama Islam (PAI) SMA', 65. 
misalnya, maka kita akan kembali pada masa romantisme sejarah, mengagungkan sejarah hingga lupa sejarah kekinian. Romantisme sejarah membuat kita lupa bahwa kita saat ini memang tertinggal dari negaranegara yang maju baik secara teknologi maupun pemikiran. Jadi sejarah hendaknya disajikan secara komprehensif, adil dan berimbang.

Untuk menggerus laju khilafah, kita bisa juga menyajikan fakta sejarah secara apa adanya dan mempromosikan Islam Moderat. Sikap moderat ini muncul dari adanya beberapa sikap umat muslim yang terlalu kekanan (liberal) dan juga terlalu ke kiri (ekstrim). Di tengah-tengah arus gerusan dan tekanan dari Barat, baik teknologi maupun pemikirannya, mau tidak mau ada usaha untuk mengembalikan kejayaan Umat islam kembali saat ini. Tepatnya seperti kemajuan Islam pada masa golden age. Setidaknya ada tiga sikap umat Islam yang bisa dijadikan landasan untuk mengembalikan kejayaan umat.

Pertama adalah ekstrimisme, yaitu mengembalikan kejayaan Islam dengan befikir ke belakang, Bercita-cita ingin meniru kejayaan khilafah beserta tatanan pemerintahannya persis seperti masa lampau. Gerakan itu menimbulkan gerakan ekstrimisme dengan menghilangkan batas-batas negara (transnasionalis) atau gerakan penegakan khilafah. Hal ini timbul karena adanya romantisme sejarah masa lampau, akibat terlalu memuja dan membaca fakta sejarah secara tidak seimbang.

Kedua, liberal yaitu mengembalikan kejayaan Islam dengan meniru kemajuan Eropa/Barat dengan segala perangkatnya, kebebasan berfikirnya, kecanggihan teknologinya semua mengadopsi dari Eropa/Barat. Kategori berfikir ini sisi negatifnya bisa menghilangkan jati diri bangsa Indonesia dan meninggalkan segala tradisi-tradisi yang melingkupinya. Maka kemudian, ke-modern yang didapatkan hanya mengekor dari negara maju tersebut dan akibatnya kita kehilangan jati diri bangsa yang sesungguhnya.

Ketiga, berfikir secara moderat yaitu tidak terlalu ke kanan dan tidak terlalu ke kiri, dengan mengembangkan salah satunya sikap Tawassuth, Tawazun dan I'tidal. Islam moderat inilah yang harus selalu kita ajarkan kepada murid-murid kita nanti. ${ }^{19}$

b. Pengembangan materi PAI berwawasan Islam Indonesia melalui pendekatan Interdisipliner dengan melibatkan ilmu psikologi untuk materi yang berkaitan dengan akhlak atau karakter. Penulis menggagas penerapan karakter ini dilandasi dengan sebuah teori yang disebut Living Value Education.

\begin{tabular}{lrr}
\multicolumn{1}{c}{ Aspek sikap } & $\begin{array}{r}\text { harus } \\
\text { dalam }\end{array}$ \\
diinternalisasi & & setidaknya \\
pembelajaran yang & semonat Thomas & Lickona, \\
menurut Than & Tilakukan melalui 3 tahapan yaitu:
\end{tabular}


moral knowing/pengetahuan moral, moral feeling/perasaan tentang moral dan moral behavior/nilai kebaikan. Deskripsi jelasnya seperti gambar di bawah ini:

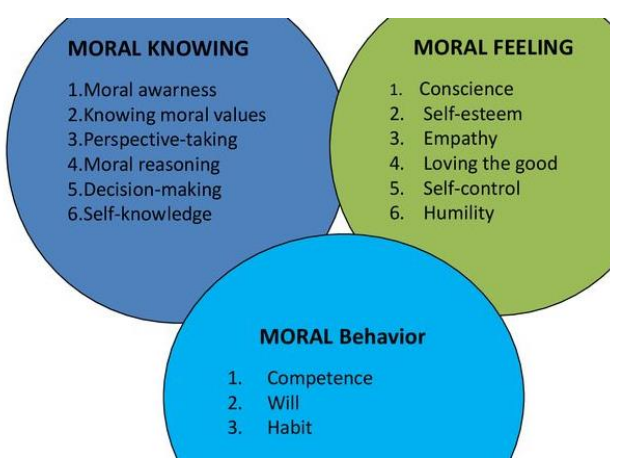

Gambar 8. Gambar Living Value Education

Sehubungan dengan hal tersebut, Lickona menyatakan karakter terdiri dari tiga bagian yang saling terkait, yaitu: pengetahuan moral, perasaan moral, dan perilaku moral.Oleh karena itu, orang yang berkarakter baik adalah orang yang mengetahui kebaikan, ingin bersikap baik dan tetap baik dalam segala urusan, sehingga muncul sebuah kebiasaan (habituasi ) baik dalam kebiasaan berfikir, sikap, dan perilaku yang berhubungan dengan urusan agama, sosial dan kehidupan pribadi. ${ }^{20}$ Prosesproses itulah yang hendaknya dipraktekkan dalam pembelajaran Akhlak di sekolah, tidak hanya melakukan proses penilaian dan penerapan karakter yang tidak jelas hasil akhirnya.

c. Pengembangan materi PAI berwawasan Islam Indonesia melalui pendekatan Interdisipliner dengan melibatkan ilmu ekologi dengan tema lingkungan. Era sekarang ini

20 Thomas Lickona, Pendidikan Karakter: Panduan Lengkap Mendidik Siswa Menjadi Pintar Dan Baik (Bandung: Nusa Media, 2018), 72. kesadaran ekologis sedikit dimiliki oleh umat muslim Indonesia. Hal yang paling mendasar misalnya, ketika membuang sampah yang tidak pada tempatnya, atau terlalu mengandalkan petugas kebersihan sehingga kemandirian tentang cinta lingkungan tidak terbentuk.

Selain itu, kesadaran untuk tidak membuang sampah di sungai juga menjadi PR besar di kalangan umat muslim Indonesia. Tidak heran kemudian munculah banjir, pencemaran sungai dari limbah dan zat-zat kimia yang berbahaya, sampah yang berserakan dimana mana dan sebagainya. Relasi antara ekologi dan teologi Islam perlu diajarkan kepada siswasiswa SMA. Agar tugas manusia sebagai khalaifatu fil-ardhi terjalankan dengan baik.

Secara teoritik Islam mengatur bahwa hubungan antara manusia dengan lingkungan bersifat apresiatif (bukan ekploitatif). Hal ini sesuai dengan Q.S. al-Jatsiyah (45): 13), Q.S. AlAn'am (6) 38. Selain itu, semua makhluk (manusia, binatang dan tumbuhan) melakukan sujud dan bertasbih atas kemuliaan penciptanya, dilarang untuk melakukan perusakan di muka bumi. Menurut ahli Tafsir M. Quraish Shihab, Jika keselarasan dan keseimbangan alam hilang maka akan terjadi kehancuran, dan dapat dipastikan bahwa kehancuran akan berdampak pada seluruh bagian alam, termasuk manusia, manusia yang merusak atau yang memberi izin untuk merusak. $^{21}$

21 M. Quraish Shihab, 'Tafsir Al-Misbah', Jakarta: Lentera Hati 2 (2002): 78. 
Oleh sebab itu, eko-teologi harus didasari dengan beberapa prinsip sehingga mampu menjawab tantangan yang nyata. Sudut pandang demikian adalah melalui perspektif hukum Islam. Pertama, Prinsip dasar hubungan manusia dengan lingkungan tidak hanya hubungan eksploitatif, tetapi juga hubungan apresiatif. Perihal ini tercover dalam Q.S. alJatsiyah (45): 13), Q.S. Al-An'am (6) 38. Kedua, Islam tidak hanya mengajarkan pembelaan soal kemanusiaan akan tetapi juga pembelaan terhadap makhluk lain. Ketiga, semua makhluk (manusia, binatang dan tumbuhan) melakukan sujud dan bertasbih atas kemuliaan penciptanya Q.S. Al-Isra (17) 44, Q.S. Al-Hajj (22) 18. Pada paparan ayat ini manusia dan makhluk lain memiliki peran dan tanggung jawab yang sama. Keempat, prinsip muhtaram (memuliakan, menghargai) harus diterapkan kepada seluruh makhluk, sebagai manifestasi memuliakan penciptanya juga. ${ }^{22}$

d. Pengembangan materi PAI berwawasan Islam Indonesia melalui pendekatan interdisipliner dengan melibatkan ilmu sosial khususnya materi gender atau tafsir Qira'ah Mubadalah. Misalnya tema penciptaan Manusia dari sejarah Adam dan Hawa, perlu sebuah tafsir perspektif baru untuk mengembalikan relasi antara lakilaki dan wanita dalam porsi yang pas.

Terjadinya bias gender yaitu subordinasi/ mengunggulkan,

22 M. Fathurrahman and dkk, 'The Qur'anic Eco-Theology: Seeking Ecological Sustainability Responding to Industrial Modernity Challenges', in ICIS 2020: Proceedings of the 2nd International stereotipe/ pelabelan negatif, marginalisasi/ meminggirkan terhadap peran besar dari seorang wanita. Misalnya perlu adanya interpretasi ulang mengenai pemahaman bahwa hawa lahir dari tulang rusuknya Nabi Adam, Hawa yang melakukan kesalahan karena memakan buah Quldi, Hawa hadir sebagi pelengkap Adam, tugas wanita hanya $3 \mathrm{M}$ (macak, manak, masak), atau hadis yang mengatakan wanita yang enggan diajak hubungan badan oleh suami, maka para Malaikat akan melaknat ia (si istri) sampai subuh. Anjuran agar istri selalu tunduk kepada suami dan ajaranajaran lainnya.

Perlu mengajarkan mengenai keadilan gender dalam Islam yaitu posisi laki-laki dan wanita dalam ajaran Islam adalah sejajar dan sama dihadapan Allah, yang membedakan adalah ketakwaan masing-masing orang. Selain itu, perlu adanya tafsir mubadalah dalam kajian Islam. Qira'ah Mubadalah merupakan Pembacaan gaya baru akan tafsir relasi antara laki-laki dan wanita, selain itu tafsir ini dapat diterapkan pada ayat-ayat gender lain yang terkandung dalam al-Qur'an. Qira'ah Mubadalah secara sederhana dapat didefinisikan sebagai sebuah pembacaan yang berorientasi pada ketersalingan pada teks-teks agama yang berbicara seputar isu-isu gender. Dalam pembacaan ini, perempuan maupun laki menjadi subjek dalam kandungan teks. Tidak ada superioritas maupun inferioritas pada salah satu jenis kelamin. Tujuannya adalah supaya terwujud keseimbangan dan keadilan baik perempuan maupun laki-laki,

Conference on Islamic Studies, ICIS 2020, 27-28 October 2020, Ponorogo, Indonesia (European Alliance for Innovation, 2021). 
Relasi yang baik antara perempuan dan laki-laki ditegaskan lagi lebih jelas dalam Q.S. at-Taubah (9): 71

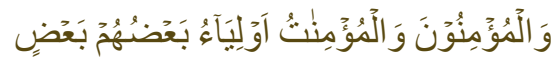

Artinya: "Dan orang-orang yang beriman, laki-laki dan perempuan, sebagian mereka menjadi penolong bagi sebagian yang lain."

Relasi yang dijelaskan dalam ayat tersebut dapat juga ditemukan dalam sabda Rasulullah bahwa wanita adalah sepadan dengan laki-laki (inna al-nisa' shaqaiq al-rijal). Kata shaqaiq yang merupakan bentuk plural dari shaqiq yang mengandung makna saudara, kembaran, serupa dan identik. Makna ini menunjukkan bahwa wanita sesungguhnya sederajat dengan laki-laki. Relasi antara mereka merupakan relasi mitra kerja dan kawan seiring yang pada gilirannya mengharuskan adanya kesalingan dalam menghormati dan menghargai pihak lain. ${ }^{23}$ Relasi antara laki-laki dan wanita ini juga bisa di masukkan dalam bab pernikahan di materi PAI SMA.

e. Pengembangan materi PAI berwawasan Islam Indonesia melalui pendekatan interdisipliner dengan melibatkan ilmu sejarah dan hukum untuk meng-counter pemahaman pemikiran pembaharuan. Ilmu sejarah untuk menggali naskahnaskah walisongo, sedangkan ilmu hukum, maqasid syar'i untuk menemukan hukum Islam dengan perspektif modernitas dan humanisme.

Pertama, pengembangan materi PAI tema masuknya Islam di Indonesia dan Walisongo. Pembahasan kali ini melibatkan kajian sejarah untuk menggali penyebaran Islam di Indonesia dilakukan secara damai melalui berbagai jalur: perdagangan, pernikahan, seni, tasawuf, dan pendidikan. Penyebaran Islam di jawa didukung oleh Walisongo. Walisongo melakukan akulturasi budaya melalui dua pemahaman. Islam dijadikan jaringan atau sebuah aturan. Adapun wadahnya bisa bermacam-macam termasuk budaya Jawa. Dalam kerangka proses filosofis dan kultural, konteks Islam ditransformasikan ke dalam realitas kehidupan oleh walisongo. Kemudian, mencoba beradaptasi dengan perkembangan realitas melalui kemungkinan penafsiran teks yang diberikan metode qawaid alfiqhiyyah dan ushul fiqh.

Namun, era sekarang ini ada beberapa upaya yang menyatakan bahwa cerita walisongo ini hanya fiktif atau karangan belaka, sehingga dijadikan penolakan untuk menerima akulturasi budaya dalam Agama Islam (purifikasi). Adanya degradasi itu dalam upaya untuk pemodelan dakwah yang tidak melibatkan tradisi. Maka harus kita counter. Upaya untuk membendung arus purifikasi yang berlebihan dengan mengharamkan berbagai tradisi yang beredar di Indonesia. Maka perlu ada kajian sejarah jawa misalnya digunakan kajian filologi dengan melibatkan teks babad tanah jawi, atau teks-teks lain yang berkembang pada masa lampau.

Untuk mendukung adanya sinkronisasi antara tradisi dan

${ }^{23}$ Faqihuddin Abdul Qodir, Qiraah Mubadalah (Yogyakarta: IRCISOD, 2019), 90. 
hadis yang menyatu di masyarakat Indonesia, maka perlu adanya penelitian dari siswa untuk mengungkap kajian living sunnah, yaitu sunnah yang berada dalam masyarakat, mengakar, dan sudah menjadi pemahaman yang utuh. Kajian ini mendorong pada pembelajaran siswa yang melibatkan realitas sosial dan tekstual melalui penelitian. Yang digali melalui dokumentasi, wawancara dan observasi. Ide penelitian tersebut misalnya:

Living Qur'an dan Hadis menuntut Ilmu

1. Dijadikan Motivasi yang dipajang di berbagai sudut

2. Dijadikan motivasi sebagai penyemangat untuk belajar

3. Menuntut ilmu sampai ke negara lain

Living Qur'an dan Hadis tentang syukur

1. Ucapan alhamdulillah

2. Tradisi syukuran

3. Semangat untuk Infaq

4. Sedekah bumi

5. Tradisi Slametan

Kedua, permasalahan adanya kebijakan bunga bank, asuransi, uang kertas, obligasi, saham perlu diajarkan tentang maqashid syar'i untuk membaca hukum Islam era modern ini. Karena berkembang pemahaman yang puritan, orang mukmin tidak boleh bekerja di bank atau asuransi karena ada dugaan unsur riba. Orang muslim juga tidak boleh bekerja di saham ataupun menjadi youtuber ataupun tiktoker karena ada dugaan keharaman di situ, dan

24 Suansar Khatib, 'Konsep Maqashid AlSyariah: Perbandingan Antara Pemikiran AlGhazali Dan Al-Syathibi', JURNAL ILMIAH MIZANI: diperbolehkannya hanya menjadi pedagang. Karena meniru Rasulullah, begitu alasan lebih lanjut. Bila ini tidak ada yang meng-counter maka masa depan anak remaja muslim akan bekerja di sektor-sektor yang terbatas. Tentunya akan terjadi keguncangan ekonomi nantinya jika remaja hanya menginginkan menjadi pedagang.

Adapun esensi dari konsep Maqasid Syari'ah yaitu untuk mencapai kebaikan serta menghindari kejahatan. Istilah yang sesuai dengan inti Maqasid Syariah adalah ke-maslahatan umat.

Menurut al-Ghazali kepentingan hukum Islam adalah segala sesuatu yang bertujuan untuk mempertahankan tujuan hukum Islam.Tujuan yang pada dasarnya terangkum dalam almabaadi 'al-khamsyah yaitu perlindungan agama (hifzd al-din), jiwa (hifzd al-nafs) pikiran (hifzd 'aql), keturunan (hifdz al-nasl) dan harta benda (hifzd al-maal). Setiap hukum yang memuat pemeliharaan lima tujuan ini disebut maslahat, dan hukum apa pun yang menghilangkan kelima unsur ini disebut mafsadah. ${ }^{24}$ Dan kita bisa menggunakan prinsipprinsip tersebut untuk menggali hukum era modern ini, misalnya untuk membaca hukum bunga bank, asuransi, pegadaian, konsep demokrasi, pancasila, dan lain sebagainya.

$\begin{array}{lrr}\text { Prosedur dan } & \text { Tahapan } \\ \text { Pengembangan } & \text { Materi } & \text { PAI }\end{array}$

Wacana Hukum, Ekonomi, Dan Keagamaan 5, no. 1 (2018): 50. 


\section{Menggunakan \\ Pendekatan Interdisipliner}

Adapun prosedur pengembangan materi PAI ini yang diaplikasikan dalam bahan ajar nantinya, berupa mengembangkan indikator dari Kompetensi Dasar yang sudah ditetapkan oleh pemerintah. Kemudian indikator ini bisa dijadikan guru sebagai pedoman untuk pengembangan materi, pembelajaran maupun penilaian. Seperti contoh berikut ini, mengenai pengembangan Indikator berbasis Interdisipliner

3.1 Menganalisis Q.S. al-Mukminun (23): 12-14 tentang fase penciptaan manusia, Q.S. an-Nahl (16): 78 tentang kesempurnaan penciptaan manusia disertai organ-organ

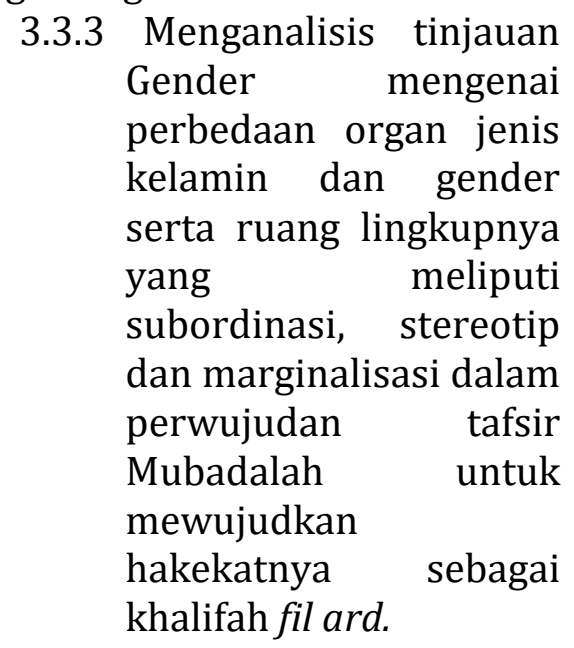

3.3 Menganalisis Q.S. ar-Rum [30]: 4142 kerusakan alam di bumi Q.S. al-A`raf [7]: 56-58 tentang larangan berbuat kerusakan di bumi

3.3.3 Menganalisis tinjauan Eko-Teologi mengenai teori min, 'an, 'ala dan fi serta prakteknya dalam penjagaan kelestarian

25 D.S. Thiagarajan, S., Semmel and M. Semmel, Instructional Development for Teaching Teachers of Exceptional Children (Bloominton: Center for Innovation on Teaching the Handicapped, 1974),

lingkungan di era
modern

Tahapan pengembangan materi PAI ini akan menggunakan model pengembangan sistem pengajaran Thiagarajan dan Semmel (1974), yaitu model 4-D yang dimodifikasi. Model 4D yang terdiri dari Define (pendefinisian), Design (perancangan), Develop (pengembangan) dan Disseminate (penyebaran) ${ }^{25}$ Namun, guru PAI dapat memodifikasi model 4-D yang disederhanakan dari empat tahap menjadi tiga tahap. Karena pertimbangan waktu dan pelaksanaan, serta pertimbangan bahwa materi PAI yang baik telah dihasilkan pada tahap Develop (pengembangan), Desseminate (penyebarluasan) tidak dilakukan.

Prosedur pengembangan meliputi tahapan-tahapan kerja yang dilaksanakan untuk mentransformasi materi PAI. Prosedur pengembangan yang dilakukan pada tiap-tiap tahapan model pengembangan dapat dijabarkan melalui

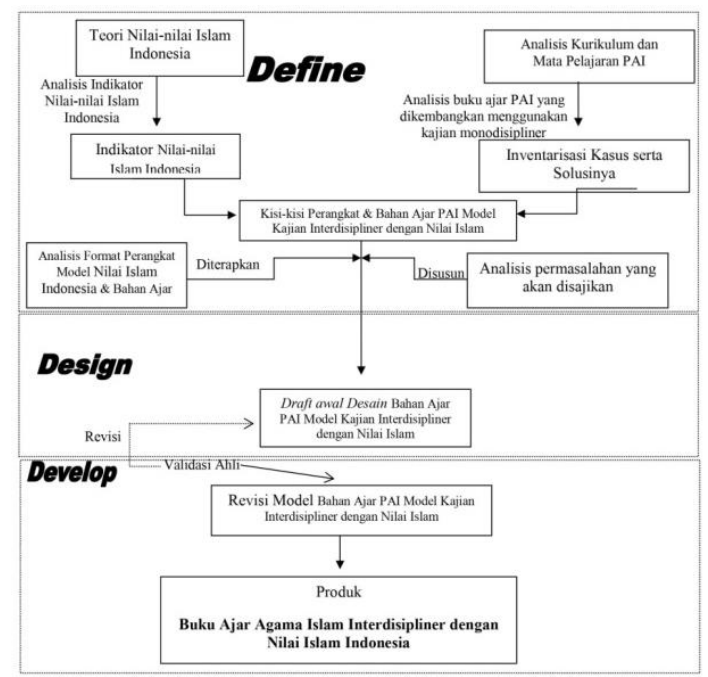

Gambar 9. Bagan Prosedur dan Tahapan Pengembangan Materi PAI pendekatan Interdisipliner dengan Nilai Islam Indonesia.

10. Lihat juga Arbain Nurdin, 'Designing PowtoonMediated Interactive Multimedia to Leverage Students' Learning Behavior in the Qur'an and Hadith', Edukasia Islamika, 2020, 158. 


\section{KESIMPULAN}

Pertama, konsep pengembangan materi PAI yang menggunakan pendekatan monodisipliner masih menggunakan satu rumpun ilmu agama saja dalam penyampaiannya, yang mengakibatkan pemahaman ekslusif dalam beragama. Misalnya persoalan khilafah, penerapan Akhlak yang masih sedikit, pengharaman tradisi, tidak peka pada persoalan lingkungan, bias gender dan pemikiran beberapa tokoh pembaharu yang mengakibatkan berfikir ekstrim. Kedua, konsep pembelajaran PAI yang menggunakan pendekatan Interdisipliner mampu menampilkan kajian beragama dengan melibatkan kajian sosial masyarakat, humanisme, persoalan lingkungan, gender, Ke-Indonesiaan, dan Politik untuk mewujudkan nilai Islam Indonesia . Prosedur dan tahapannya menggunakan Model 4-D terdiri dari Define (pendefinisian), Design (perancangan), Develop (pengembangan) dan Disseminate (penyebaran)

\section{REFERENSI}

Durhan, Durhan. 'Integrasi Nilai-Nilai Nasionalisme dalam Pendidikan Agama Islam dengan Pendekatan Interdisipliner'. Ahsana Media 6, no. 1 (2020): 51-60.

Faqihuddin Abdul Qodir. Qiraah Mubadalah. Yogyakarta: IRCISOD, 2019.

Harold, Rudy. 'Agama dan Pembentukan Realitas dalam Pandangan Peter Ludwig Berger'. Cakrawala 5, no. 1 (2016).

Hasyim, Arrazy. 'Teologi Muslim Puritan: Genealogi dan Ajaran Salafi', 2017.

Muzakki, Hawwin. 'Integrasi Nilai-Nilai Religius dan Nasionalisme pada Pendidikan Anak Usia Dini'. In Prosiding ISLAGE-2 Kemenag RI. sentul, Bogor, n.d. Accessed 21 April 2021.

Indrianto, Nino. 'Rancangan Bahan Ajar Pendidikan Agama Islam Dengan Pendekatan Interdisipliner Di
Perguruan Tinggi: Studi Pengembangan di Fakultas Keguruan dan Ilmu Pendidikan Universitas Jember dan Fakultas Ilmu Pendidikan Universitas Negeri Surabaya'. PhD Thesis, UIN Sunan Ampel Surabaya, 2019.

Jawahir Gustav Rizal. 'Terjadi Ledakan Bom Bunuh Diri, Gereja Katedral Makassar Trending di Twitter Halaman all'. KOMPAS.com, 30 March 2021.

Kementerian Agama Republik Indonesia. Pendidikan Agama Islam Dan Budi Pekerti Kelas X Revisi 2019. Jakarta: Kementerian Agama, 2019.

_. Pendidikan Agama Islam Dan Budi Pekerti Kelas XI Revisi 2019. Jakarta: Kementerian Agama, 2019.

_. Pendidikan Agama Islam Dan Budi Pekerti Kelas XII Revisi 2019. Jakarta: Kementerian Agama, 2019. Khatib, Suansar. 'Konsep Maqashid AlSyariah: Perbandingan Antara Pemikiran Al-Ghazali Dan AlSyathibi'. Jurnal Ilmiah Mizani: Wacana Hukum, Ekonomi, Dan Keagamaan 5, no. 1 (2018): 47-62.

M. Fathurrahman and dkk. 'The Qur'anic Eco-Theology: Seeking Ecological Sustainability Responding to Industrial Modernity Challenges'. In ICIS 2020: Proceedings of the 2nd International Conference on Islamic Studies, ICIS 2020, 27-28 October 2020, Ponorogo, Indonesia. European Alliance for Innovation, 2021.

Mudawinun, Khoirul. 'Integrasi NilaiNilai Moderasi Pada Pendidikan Anak Usia Dini Berbasis Living Values Education (LVE)'. In Proceedings of Annual Conference for Muslim Scholars, 721-30, 2018.

Muzakki, Hawwin. 'Mengukuhkan Islam Nusantara: Kajian Sosiologis-Historis'. An-Nuha: Jurnal Kajian Islam, Pendidikan, Budaya Dan Sosial 6, no. 2 (10 December 2019): 21539. 
Nimawati, Nimawati, Uus Ruswandi, and Mohamad Erihadiana. 'Kajian Riset Monodisipliner dan Interdisipliner dalam pendidikan islam Menghadapi Isu Nasional dan Global: Studi Kasus Terhadap Isu Covid-19'. Misykat: Jurnal Ilmu-ilmu AlQuran, Hadist, Syari'ah dan Tarbiyah 5, no. 1 (30 June 2020): 101-22. https://doi.org/10.33511/misykat.v5 n1.101-122.

Nur, Afrizal. 'Konsep Wasathiyah dalam Al-Quran; (Studi Komparatif antara Tafsir Al-Tahrîr Wa At-Tanwîr dan Aisar At-Tafâsîr)'. Jurnal An-Nur 4, no. 2 (27 September 2016).

Nurdin, Arbain. 'Designing PowtoonMediated Interactive Multimedia to Leverage Students' Learning Behavior in the Qur'an and Hadith'. Edukasia Islamika, 2020, 158-74.

Palupi Annisa Auliani. 'Lokasi Ledakan Bom Surabaya dalam Peta'. KOMPAS.com, 13 May 2018. https://regional.kompas.com/read/2018/05/13 /17512651/lokasi-ledakan-bom-surabaya-dalam-peta.

Shihab, M. Quraish. 'Tafsir Al-Misbah'. Jakarta: Lentera Hati 2 (2002).

Syafruddin, Didin. 'Analisis Muatan Radikalisme Dalam Buku Teks Pendidikan Agama Islam (PAI) SMA'. Master's Thesis, Jakarta: FITK UIN Syarif Hidayatullah Jakarta, n.d.

Thiagarajan, S., Semmel, D.S., and M. Semmel. Instructional Development for Teaching Teachers of Exceptional Children. Bloominton: Center for Innovation on Teaching the Handicapped, 1974.

Thomas Lickona. Pendidikan Karakter: Panduan Lengkap Mendidik Siswa Menjadi Pintar Dan Baik. Bandung: Nusa Media, 2018. 
Transformasi Pengembangan Materi Pendidikan Agama Islam Dengan Nilai Islam Indonesia (dari Pendekatan Monodisipliner menuju Pendekatan Interdisipliner) | Hawwin Muzakki, Ahmad Natsir, Ahmad Fahrudin 